\title{
PENGARUH PENGALAMAN KERJA, INDEPENDENSI, INTEGRITAS, OBYEKTIVITAS DAN KOMPETENSI TERHADAP KUALITAS AUDIT
}

\author{
Veby Kusuma Wardhani \\ Magister Akuntansi Fakultas Ekonomi dan Bisnis Universitas Brawijaya Malang \\ E-mail: veby.wardhani@gmail.com \\ Iwan Iriyuwono, Muhammad Achsin \\ Fakultas Ekonomi dan Bisnis Universitas Brawijaya Malang
}

\begin{abstract}
This study is specifically to evaluate the effect of work experience, independence, integrity, objectivity and competence toward the audit quality. This study was conducted by distributing questionnaires to KAP in Malang. By counting related association division of KAP, the number of sample in this study was 63 respondents who definitely worked in 7 KAP. This research is a quantitative study. The sample was chosen by using purposive sampling. The hypothesis test used multiple linear regressions in SPSS version 16. All variables in this study were measured using Likert Scale. The results shows that all independent variables have positive effect toward audit quality. The partial influence (T-test) showed that the variables of work experience, Independence, Integrity, Objectivity, Competence affect audit quality. In the other hands, the simultaneous effect is shown by the value of $\mathrm{R}^{2}$ from $75.2 \%$. It was shown by work experience, independence, integrity, objectivity, and competence which affecting audit quality changing of $75.2 \%$ and the rest, $24.8 \%$ in audit quality changing, is affected by other variables which is not investigated in this study.
\end{abstract}

Keywords: Work Experience, Independence, Integrity, Objectivity, Competence and Audit Quality.

\begin{abstract}
Abstrak
Penelitian ini khusus untuk mengevaluasi hubungan pengalaman kerja, independensi, integritas, objektivitas dan kompetensi terhadap kualitas audit. Penelitian ini dilakukan dengan menyebarkan kuesioner kepada KAP di Malang. Dengan bagian asosiasi tujuan KAP, jumlah sampel penelitian adalah 63 responden yang bekerja di 7 KAP. Penelitian ini merupakan studi kuantitatif. Penentuan sampel menggunakan purposive sampling. Uji hipotesis menggunakan regresi linier berganda dengan SPSS versi 16. Semua variabel dalam penelitian ini diukur dengan Skala Likert. Hasil penelitian menunjukkan semua variabel independen memiliki efek positif terhadap kualitas audit. Pengaruh parsial (T test) menunjukkan bahwa variabel pengalaman kerja, Independence, Integritas, Obyektivitas, Kompetensi mempengaruhi kualitas audit. Sedangkan pengaruh secara simultan ditunjukkan dengan nilai $\mathrm{R}^{2}$ dari $75.2 \%$. Itu adalah pengalaman kerja, independensi, integritas, objektivitas, dan kompetensi mempengaruhi perubahan kualitas audit dari $75.2 \%$ dan $24.8 \%$ yang tersisa dalam perubahan kualitas audit dipengaruhi oleh variabel lain yang tidak diteliti dalam penelitian ini.
\end{abstract}

Kata kunci: Pengalaman Kerja, Bebas, Integritas, Objektivitas, Kompetensi dan Kualitas Audit. 
Profesiakuntan publik mulai dikenal oleh masyarakat dari jasa audit yang yang disediakan bagi pemakai informasikeuangan. Timbul dan berkembangnya profesi akuntan publik di suatu negara sejalan dengan berkembangnya perekonomian negara, pertumbuhan perusahaan dan berbagai bentuk badan hukum perusahaan di negara tersebut. Perusahaan membutuhkan jasa akuntan publik dan pihak terasosiasi untuk melakukanpemeriksaan atas kewajaran laporan keuangan dan dari hasil pemeriksaan tersebut akan menghasilkan opini akuntan publik yang digunakan para pengguna laporan keuangan ekstern dan intern perusahaan untuk pengukuran apakah manajemen keuangan perusahaan telah berjalan dengan baik dan sesuai dengan standar yang berlaku.

Hasil pekerjaan yang baik dari audit yang dilakukan, menunjukkan kualitas audit yang baik pula. Kualitas audit adalah probabilitas di mana seorang auditor menemukan dan melaporkan tentang adanya suatu pelanggaran dalam sistem akuntansi kliennya (Sanusi, 2013: 213). Kualitas audit merupakan suatu konstruk laten yang sulit untuk diukur sehingga banyak proksi digunakan untuk mengukurnya. Proksi tersebut antara lain, spesialisasi auditor, besaran KAP, afiliasi dengan KAPbesar (Kusharyanti, 2003:25). Sementara itu penelitian dari Purwanti et al proksi yang digunakan dalamkualitas audit berdasarkan wooten (2003) adalah (1) deteksi salah saji, (2) kesesuaian dengan SPAP, (3) kepatuhan terhadap SOP, (4) risiko audit, (5) prinsip kehatihatian, (6) proses pengendalian atas pekerjaan oleh supervisor, dan (7) perhatian yang diberikan oleh manajer atau partner.

Profesionalisme auditor didukung oleh kualitas audit yang dihasilkan. Profesionalisme auditor tidak lepas dari kemampuan melakukan pemeriksaan atau audit sesuai standar auditor yang berlaku. Kemampuan me- lakukan pemeriksaan itu sendiri dapat dipengaruhi oleh pengalaman kerja auditor dalam bidang yang sama. Pengalaman audit ditunjukkan dengan jumlah penugasan audit yang pernah dilakukan. Pengalaman seorang auditor menjadi salah satu faktor yang mempengaruhi profesional auditor karena auditor yang lebih berpengalaman dapat mendeteksi adanya kecurangan-kecurangan pada laporan keuangan (Sabrina dan Januarti, 2012). Pengalaman juga memberikan dampak pada setiap keputusan yang diambil dalam pelaksanaan audit sehingga diharapkan bahwa setiap keputusan yang diambilmerupakan keputusanyang tepat.

Berdasarkan penelitian tersebut menunjukkan adanya gap dari beberapa penelitian sehingga memerlukan pengujian ulang atas pengaruh faktor-faktor yang memengaruhi kualitas audit. Banyak penelitian melihat kualitas audit dari kemampuan untuk menemukan salah saji(kompetensi) dan kemauanuntuk melaporkan temuan salah saji tersebut (independensi). Namun juga ada beberapa penelitiyang telah mengembangkan faktor-faktor yang dapat memengaruhi kualitas audit dari kemampuan auditor (meliputi pengetahuan, pengalaman, kemampuan beradaptasi, dan kecanggihan tekonologis) dan professional conduct (termasuk di dalamnya independensi, objektivitas, kemahiran profesional, konflik kepentingan, dan pertimbangan).

Oleh karena itu penelitian ini mencoba mengkaji ulang mengenai faktor-faktor yang mempengaruhi kualitas audit dengan memfokuskan faktor dari kemampuan auditor, yaitu pengalaman kerja dan profesionalisme meliputi independensi, integritas, obyektivitas dan kompetensi, yang merupakan bagian dari kode etik audit. Auditor yang memiliki pengalaman kerja auditor tinggi akan lebih cermat dalam melakukan pemeriksaan se- 
hingga kualitas audit yang dihasilkan tak diragukan lagi, karena adanya expectation gap (perbedan antara keinginan atau harapan masyarakat terhadap hasil kerja auditor dengan hasil kerja yang ditunjukkan oleh auditor) terjadi karena kurangnya pengalaman kerja dan pengetahuan (kompetensi) yang dimiliki hanya sebatas pada bangku kuliah saja dan hal ini menunjukkan adanya keterikatan antara variabel pengalaman kerja dengan variabel kompetensi di mana auditor yang berkompeten akan terus melakukan up grade pengetahuan dan bekerja secara profesional. Semakin lama auditor bekerja maka semakin luas pengetahuan yang dimilikidan semakin tinggi pula tingkat penguasaan bidangnya. Untuk variabel Independensi dinyatakan secara jelas dalam SPAP SA seksi 220 bahwa dalam semua hal yang berhubungan dengan penugasan independensi dalam sikap mental harus dipertahankan oleh auditor. Auditor yang independen tidak memiliki hubungan dan kepentingan khusus terhadap klien sehingga tidak mendapat tekanan darimanajemen atau klien yang mungkin terjadi selama proses audit, karena kemampuan auditor untuk tetap independen akan mempengaruhi pemberian pendapat audit. Hal ini akan berkorelasi positif dengan variabel integritas dan obyektivitas, di mana auditor yang berintegritas tinggi akan mampu untuk bersikap hati-hati, tegas, adil dan mengungkapkan semua hal yang material dalam temuan auditnya dan tetap obyektif dalam penugasan dan tidak membiarkan pengaruh dari pihak lain secara subyektif. Auditor agar dapat bersikap independen, auditor harus kompeten secara intelektual, harus dapat menjaga integritasnya dan tetap obyektif dalammelakukan pemeriksaan. Berdasarkan uraian di atas menunjukkan bahwa auditor harus memiliki kesatuan karakteristik yaitu pengalaman kerja, independensi, in- tegritas, obyektivitas dan kompetensi untuk menghasilkan laporan audit yang berkualitas.

\section{Metode Penelitian}

Populasi dalam penelitian ini yaitu pihak terasosiasi yang berada dalam naungan KAP di Kota Malang. Berdasarkan jumlah kantor akuntan publik di Kota Malang yang berjumlah tujuh KAP(Sumber:Directory 2013 Institut Akuntan Publik Indonesia). Sampel dalam penelitian ini dilakukan pada pihak terasosiasi/ Pihak terasosiasi berkaitan atau berhubungan langsung dalam proses audit yang dilakukan oleh KAP. Teknik pengambilan sampel atau teknik sampling yang digunakan yaitu Purposive Sampling.

Pengalamankerja, yaitu Pengalamankerja akuntan publik adalah sebagai suatu ukuran waktu atau masa kerjanya yang telah ditempuh seseorang dalam memahami tugastugas suatu pekerjaan dan telah melaksanakannya dengan baik (Foster, 2001:40). Indikator pengalaman kerja menurut Foster (2001: 43) adalah: Lama waktu masa kerja, Tingkat pengetahuan dan keterampilan yang dimiliki, Penguasaan terhadap pekerjaan dan peralatan.

Independensi adalah suatu sikap tak mudah dipengaruhi, tidak memihak kepada kepentingan siapapun, bebas dari setiap kewajiban terhadap kliennya dan tidak mempunyai suatu kepentingan dengan kliennya, baik itu manajemen perusahaan maupun pimpinan perusahaan (Standar Profesional Akuntan Publik (2001:220). Indikator independensi berdasarkan pengertian di atas adalah: (a) Tidak ada pengaruh secara emosional, dan keuangan dari klien. (b) Tidak memihak kepentingan manajemen dan pemilik perusahaan, kreditur dan pihak lain yang meletakkan kepercayaan atas laporan auditor (c) Auditor selalu bersikap independen. Yang 
ketiga Integritas, yaitu indikator independensi berdasarkan pengertian di atas adalah: (a) Tidak ada pengaruh secara emosional, dan keuangan dari klien. (b) Tidak memihak kepentingan manajemen dan pemilik perusahaan, kreditur dan pihak lain yang meletakkan kepercayaan atas laporan auditor. (c) Auditor selalu bersikap independen.

Obyektivitas yaitu merupakan suatu prinsip yang mengharuskan praktisi untuk tidak membiarkan subyektivitas, benturan-benturan kepentingan, atau pengaruh yang tidak layak dari pihak-pihak lain yang dapat memengaruhi pertimbangan profesional atau pertimbangan bisnisnya (IAPI, 2009:120). Indikator obyektivitas adalah menurut (IAPI, 2009:120): (a) Menghindari setiap hubungan yang bersifat subjektif. (b) Menghindari pemberian atau hubungan atau dapat mengakibatkan pengaruh yang tidak layak terhadap pertimbangan profesionalnya.

Kompetensi, Menurut IAPI (2009:130) Kompeternsi adalah sikap kecermatan dan kehati-hatian profesional seorang auditor. Menurut prinsip komptensi, mewajibkan seorang auditor/praktisi untuk memelihara pengetahuan, keahlian dan kemahiran profesionalnya. Indikator kompetensi adalah (IAPI, 2009:130): (a) Memelihara pengetahuan dankeahlian profesional yang dibutuhkan untuk menjamin pemberian jasa profesional yang kompeten kepada klien atau pemberi kerja. (b) Menggunakan kemahiran profesionalnya dengan seksama sesuai dengan standar profesi dan kode etik profesi yang berlaku dalam memberikan jasa profesionalnya.

Kualitas audit, kualitas audit yaitu suatu proses yang menunjukkan kompetensi dan independensi auditor dalam menjalankan pemeriksaan auditnya mulai dari proses deteksi salah saji, kepatuhan terhadap standar operasional prosedur (SOP), resiko audit, prinsip kehati-hatian, proses pengendalian oleh supervisor, dan perhatian oleh manager/ partner (Wooten, 2003). Indikator kualitas audit menurut Wooten, (2003) adalah Deteksi salah saji, Kepatuhan terhadap SOP, Risiko audit, Prinsip kehati-hatian, Proses Pengendalian atas pekerjaan oleh supervisor, Perhatian yang diberikan oleh manajer atau partner.

\section{Hasil Penelitian dan Pembahasan}

Dari 63 kuesioner yang diolah, berdasarkan jabatan diketahui yang berkedudukan sebagai auditor senior adalah sebesar 20 responden $(31,7 \%)$ dan auditor junior sebesar $43(68,3 \%)$. Berdasarkan usia diketahui sebagian besar usia responden berkisar antara 28-34 sebesar 47,62\%. Selanjutnya adalah usia 21-27 sebesar 38,10\%. Usia 35-41 sebesar 5,35\%, usia 42-48 sebesar 5,35\%, dan yang terkecil usia 56-62 sebesar 1,59\%. Berdasarkan jenis kelamin menunjukkan bahwa jumlah responden yang berjenis kelamin laki-laki sebesar 71,43\% sedangkan yang berjenis kelamin perempuan sebesar $28,57 \%$. Berdasarkan pendidikan formal responden, sebagian besar pendidikan responden adalah $\mathrm{S} 1$ yaitu sebesar $84,1 \%$ sedangkan sisanya sebesar $15,9 \%$ berpendidikan S2. Berdasarkan lama bekerja sebagai auditor, bahwa sebagian besar responden yang diamatimemiliki lama bekerja sebagai auditor selama 1-5 tahun, sebesar 85,7\%. Masa kerja 6-10 tahun sebesar 9,5\%. Masa kerja 11-15 tahun sebesar 3,2\% dan masa kerja 26-30 tahun sebesar 1,6\%.

Uji validitas digunakan untuk mengukur sah atau valid tidaknya suatu kuesioner. Suatu koesioner dikatakan valid jika pertanyaan pada kuesioner mampu untuk mengungkapkan sesuatu yang akan diukur oleh kuesioner tersebut (Ghozali, 2007:45). Syarat minimum instrumen dinyatakan valid dan tidak valid menurut Sugiyono (2008:178): Bila 
harga korelasi di bawah 0,30, maka dapat disimpulkan butir instrumen tersebut tidak valid, sehingga harus diperbaiki atau dibuang. Dengan demikian instrumen dianggap memenuhi syarat apabila $r=0,3$. Berdasarkan hasil uji validitas menunjukkan bahwa semua item dari variabel yang diamati memiliki nilai product moment (r) di atas 0,3. Dengan demikian dapat dikatakan bahwa kuisioner yang digunakan memenuhi criteria valid atau dapat digunakan untuk mengukur variabel. Dengan hasil tersebut, maka kuisioner dapat dianalisis lebih lanjut.

Reliabilitas adalah alat untuk mengukur suatu kuesioner yang merupakan indikator dari variabel atau konstruk. Suatu konstruk atau variabel dikatakan reliabel jika memberikan nilai cronbach alpha lebih besar 0,6 (Ghozali, 2007:41-42). Hasil pengujian reliabilitas menunjukkan bahwa nilai $\alpha$ chonbach dari masing-masing variabel berada di atas 0,6. Dengan demikian kuesioner dapat dikatakan reliabel dan dapat diolah lebih lanjut.

Untuk menjawab tujuan penelitian dan menguji hipotesis dilakukan dengan analisis statistik regresi linier berganda menggunakan bantuan Statistical Package for the Social Science. (SPSS).

Pengujian asumsiklasik digunakanmenyakini bahwa persamaan regresi yang dihasilkan tidak terdapat variabel terganggu yang dapat mengganggu prediksi dari persamaan regresi. Tujuannya agar memperoleh nilai pemerkira yang tidak bias. Pengujian asumsi klasik yang dilakukan adalah sebagai berikut:

Autokorelasi bertujuan untuk menguji apakah dalam sebuah model regresi linier ada korelasi antara kesalahan pengganggu pada periode $t$ dengan kesalahan pada periode t-1 (sebelumnya). Hasil uji autokorelasi dengan run test didapatkan nilai z run test sebesar -1,650 dengan sig sebesar 0,099.
Karena Asymp sig > $\alpha(0,05)$ sehingga tidak terjadipermasalahan autokorelasi dan asumsi diterima.

Ujimultikolinieritas bertujuan untuk menguji apakah pada model regresi ditemukan adanya korelasi antar variabel bebas (independen) (Ghozali, 2007:91). Hasil uji multikolineritas dengan VIF menunjukkan bahwa semua variabel bebas memiliki nilai VIF dibawah 10. Dengan demikian tidak terjadi permasalahan multikolinieritas dan asumsi diterima.

Uji Heterokedastisitas bertujuan menguji apakah dalam sebuah model regresi, terjadi ketidaksamaan varians dari residual dari satu pengamatan ke pengamatan yang lain (Ghozali, 2007:105). Hasil uji heterokedastisitas dengan uji glejser menunjukkan bahwa nilai sig $t$ dari semua variabel bebas di atas $0,05(\alpha=5 \%)$ atau sig $\mathrm{t}>\alpha(0,05)$. Dengan demikian tidak terjadi permasalahan heterokedastisitas dan asumsi diterima.

Uji Normalitas bertujuan menguji apakah dalam sebuah regresi, variabel dependent, variabel independent atau keduanya mempunyai distribusinormal Ghozali, 2007: 110). Hasil uji normalitas dengan kolmogorof smirnov menunjukkan bahwa nilai Kolmogorov-Smirnov Z 0,648 dengan Asymp sig Z kolmogorof smirnov sebesar 0,796. Karena asymp sig > á $(0,05)$ maka dikatakan data terdistribusi normal dan asumsi diterima.

Berdasarkan hasil uji regresi menunjukkan bahwa persamaan regresi telah memenuhi uji asumsi klasik, sehingga dapat digunakan untuk analisis lebih lanjut. Berdasarkan uji regresi dapat diketahui bahwa secara bermakna (bersama-sama) pengalaman kerja, independensi, integritas, obyektivitas, dankompetensimemengaruhi perubahan kualitas audit. Besarnya pengaruh secara bermakna ditunjukkan dengan nilai $\mathrm{R}^{2}$ 
sebesar $0,752(75,2 \%)$. Artinya pengalaman kerja, independensi, integritas, obyektivitas, dan kompetensi memengaruhi perubahan kualitas audit sebesar 75,2\% sedangkan sisanya sebesar $24,8 \%$ perubahan kualitas audit dipengaruhi oleh variabel lain di luar model regresi.

Nilai t hitung pengalaman kerja sebesar 2,535 dengan sig t sebesar $0,014<0,05(\alpha 5 \%)$. Dengan demikian Ho ditolak dan Ha diterima, sehingga pengalaman kerja memengaruhiperubahan kualitas audit. Nilait hitung independensi sebesar 2,167 dengan sig t sebesar $0,034<0,05(\alpha 5 \%)$. Dengan demikian Ho ditolak dan Ha diterima, sehingga independensi memengaruhi perubahan kualitas audit.

Nilai t hitung integritas sebesar 2,723 dengan sig t sebesar 0,009 <0,05 (á 5\%). Dengan demikian Ho ditolak dan Ha diterima, sehingga integritas memengaruhi perubahan kualitas audit. Nilai t hitung obyektivitas sebesar 2,491 dengan sig t sebesar $0,016<0,05(\alpha 5 \%)$. Dengan demikian Ho ditolak dan Ha diterima, sehingga obyektivitas memengaruhi perubahan kualitas audit. Nilai t hitung kompetensi sebesar 4,079 dengan sig t sebesar $0,000<0,05(\alpha 5 \%)$. Dengan demikian Ho ditolak dan Ha diterima, sehingga kompetensi memengaruhiperubahan kualitas audit.

Dapat disimpulkan secara parsial semua variabel memengaruhi perubahan kualitas audit. Jika dilihat dari nilai koefisien regresi (b) dari masing-masing variabel bebas, maka nilai koefisien regresi yang tertinggi dihasilkan oleh variabel kompetensi, yaitu sebesar 0,800 . Dengan demikian dapat dikatakan bahwa kompetensi merupakan variabel yang memiliki pengaruh dominan terhadap perubahan kualitas audit, dibandingkan variabel pengalaman kerja, independen, in- tegritas dan obyektivitas. Berdasarkan Tabel 5.12 dapat disusun persamaan regresi sebagai berikut.

$Y=a+b_{1} X_{1}+b_{2} X_{2}+b_{3} X_{3}+b_{4} X_{4}+b \ldots$ $\boldsymbol{X}_{5}$

Kualitas audit $=-12,886+0,477$ pengalaman kerja $+0,304$ independensi $+0,504$ integritas $+0,689$ obyektivitas $+0,800$ kompetensi

Nilai konstantas sebesar -12,886 artinya jika pengalaman kerja, independensi, integritas, obyektivitas dan kompetensi bernilai nol, maka secara konstan nilai kualitas audit sebesar -12,886. Nilai koefisien regresi pengalaman kerja sebesar 0,477 artinya setiap kenaikan satu satuan pengalaman kerja, akan meningkatkan kualitas kerja sebesar 0,477 . Nilai koefisien regresi independensi sebesar 0,304 artinya setiap kenaikan satu satuan independensi, akan meningkatkan kualitas kerja sebesar 0,304. Nilai koefisien regresi integritas sebesar 0,504 artinya setiap kenaikan satu satuan integritas, akan meningkatkan kualitas kerja sebesar 0,504. Nilai koefisien regresi obyektivitas sebesar 0,689 artinya setiap kenaikan satu satuan obyektivitas, akan meningkatkan kualitas kerja sebesar 0,689. Nilai koefisien regresi kompetensi sebesar 0,800 artinya setiap kenaikan satu satuan kompetensi, akan meningkatkan kualitas kerja sebesar 0,800.

Pengalaman Auditor adalah pengalaman dalam melakukan audit laporan keuangan baik dari segi lamanya waktu, banyaknya penugasan maupun jenis-jenis perusahaan yang pernah ditangani. Makin banyak pengalaman Auditor yang semakin luas dapat menghasilkan berbagai macam dugaan dalam menjelaskan temuan audit.

Berdasarkan hasil analisis diketahui bahwa pengalaman kerja memengaruhi perubahan kualitas audit secara positif. Artinya 
kenaikan pengalaman kerja seorang auditor, akan meningkatkan kualitas audit yang dihasilkan oleh auditor tersebut. Berpengaruhnya pengalaman kerja terhadap kualitas audit karena pengalaman kerja yang dimiliki oleh seorang auditor akan memperluas wawasan auditor dalam menemuhi dan mengatasi permasalahan-permasalahan yang ada dilapangan, sehingga auditor akan lebih mampu untuk menjelaskan temuan audit.

Auditor yang lebih berpengalaman juga lebih mampu member penjelasan yang masuk akal atas kesalahan-kesalahan dalam laporan keuangan dan dapat mengelompokkan kesalahan berdasarkan tujuan audit dan struktur dari sistemakuntansi yang mendasari(Martin, 2011). Auditor yang berpengalaman juga memiliki ketelitian dan kemampuan yang baik dalam menyelesaikan setiap pekerjaannya (Indah, 2010) sehingga kualitas audit yang dihasilkan akan menjadi lebih akurat.

Pengalaman kerja dapat memperdalam dan memperluas kemampuan kerja. Semakin sering seseorang melakukan pekerjaan yang sama, semakin terampil dan semakin cepat dia menyelesaikan pekerjaan tersebut. Semakin banyak macam pekerjaan yang dilakukan seseorang, pengalaman kerjanya semakin kaya dan luas, dan memungkinkan peningkatan kinerja (Kusuma, 2012).

Auditor harus dapat mengumpulkan setiap informasi yang dibutuhkan dalam pengambilan keputusan audit di mana hal tersebut harus didukung dengan sikap independen. Independensi auditor berhubungan dengan perilaku etis auditor. Artinya auditor yang lebih independen akan cenderung berperilaku etis (Samsi, 2013)

Hasil analisis menunjukkan bahwa independensi memengaruhi perubahan kualitas audit secara positif. Artinya setiap kenaikan independensi yang dimiliki auditor dalammelaksanakan audit, akan meningkatkan kualitas audit. Berpengaruhnya independensi terhadap kualitas audit karena auditor yang lebihindependen akanlebihmudahuntuk menjaga perilaku etisnya (Samsi, 2013). Auditor yang independen, juga akan selalu menjaga sikap jujur, tidak memihak siapapun, sehingga hasil audit yang dihasilkan bersifat obyektif dandapat dipercaya oleh seluruh pihak yang berkepentingan.

Integritas dapat menerima kesalahan yang tidak disengaja dan perbedaan pendapat yang jujur, tetapi tidak dapat menerima kecurangan prinsip. Denganintegritas yang tinggi, maka auditor dapat meningkatkan kualitas hasil pemeriksaannya (Sukriah, Akram dan Inapty, 2013).

Hasil penelitian menunjukkan bahwa integritas memengaruhi kualitas audit secara positif. Artinya kenaikan integritas seorang auditor akan meningkatkan kualitas audit. Berpengaruhnya integritas terhadap kualitas audit karena seorang auditor yang memegang prinsip integritas yang tinggi, akan lebih berperilaku etis, tidak dapat menerima kecurangan, sehingga audit yang dihasilkan lebih dapat dipercaya kebenarannya.

Hubungan keuangan dengan klien dapat mempengaruhiobyektifitas dandapat mengakibatkan pihak ketiga berkesimpulan bahwa obyektifitas auditor tidak dapat dipertahankan. Dengan adanya kepentingan keuangan, seorang auditor jelas berkepentingan dengan laporan hasil pemeriksaan yang diterbitkan. Standar umum dalam Standar Audit menyatakan bahwa dengan prinsip obyektifitas mensyaratkan agar auditor melaksanakan audit dengan jujur dan tidak mengkompromikan kualitas. Dengan kata lain, semakin tinggi tingkat obyektifitas auditor maka semakin baik kualitas hasil pemeriksaannya (Sukriah, Akram dan Inapty, 2013).

Hasil penelitian menunjukkan bahwa obyektivitas terbukti berpengaruh terhadap 
kualitas audit secara positif. Artinya peningkatan sikap obyektivitas auditor akan meningkatkan kualitas audit yang dihasilkan. Berpengaruhnya obyektivitas terhadap kualitas audit karena sikap obyektivitas yang dimiliki auditor akan menjadikan auditor bersikap jujurdan tidakmengkompromikan hasilaudit dengan kepentingan beberapapihak, sehingga hasil audit menjadi lebih dapat dipercaya oleh semua pihak yang berkepentingan.

Hasil penelitian ini mendukung penelitian yang dilakukan oleh Carolita (2012) yang mampu membuktikan adanya pengaruh obyektivitas terhadap kualitas audit.

Seorang auditor menjadi ahli terutama diperoleh melaluipelatihan dan pengalaman. Seorang auditor yang lebih berpengalaman akan memiliki skema lebih baik dalam mengidentifikasi kekeliruan-kekeliruan daripada auditor yang kurang berpengalaman. Sehingga pengungkapan informasi tidak lazim oleh auditor yang berpengalaman juga lebih baik dibandingkan pengungkapanoleh auditor yang kurang berpengalaman(Libby, 1991 dalam Indah, 2010). Semakin tinggi kompetensi auditor akan semakin baik kualitas hasil pemeriksaannya (Samsi, 2013).

Hasil analisis menunjukkan bahwa kompetensi terbukti mempengaruhi kualitas audit secara positif. Artinya peningkatan kompetensi seorang auditor akan meningkatkan kualitas audit yang dihasilkannya. Berpengaruhnya kompetensi terhadap kualitas audit karena auditor yang memiliki pendidikan yang lebih tinggi, baik yang didapatkan dari pendidikan formal maupun pendidikan non formal akan meningkatkan kemampuan auditor untukmemahamiprosedur, mengidentifikasikan setiap permasalahan, sehingga lebih kualitas audit yang dihasilkan menjadi lebih baik.

Auditor yang berpendidikan akan mempunyai pandangan yang lebih luas mengenai berbagai hal. Auditor akan lebih mudah da- lam mengikuti perkembangan jaman yang semakin kompleks sehingga tingkat keberhasilan melaksanakan audit akan lebih tinggi dan lebih berkualitas. Pengetahuan yang semakin luas juga meningkatkan kemampuan auditor secara spesifik dan membantu mencapai kinerja auditor (Indah, 2010).

\section{Penutup}

Berdasarkan analisis data dan pembahasan pada 63 sampel di 7 Kantor Akuntan Publik yang terdaftar pada Directory 2013 IAPI, maka dapat ditarik kesimpulan sebagai berikut: Hasil pengujian validitas dan realibilitas untuk seluruh variabel menunjukkan hasil yang baik. Pengujian terhadap setiap item pertanyaan dengan menggunakan korelasiproduct moment menunjukkkan bahwa setiap butir pertanyaan valid, yakni nilai product moment (r) di atas 0,3 dan untuk realibilitas setiap instrumen dengan Croanbach Alpha menunjukkan bahwa memilikinilai yang lebih besar dari 0,60 yang menunjukkan setiap item pertanyaan reliable. Pengujian hipotesis menunjukkan bahwa variabel Pengalaman Kerja, Independensi, Integritas, Obyektivitas dan Kompetensi memilikipengaruh terhadap Kualitas Audit. Hasil pengujian koefisien determinasi $\left(\mathrm{R}_{2}\right)$ sebesar 0.752 menujukkan bahwa $75,2 \%$ pengalaman kerja, independensi, integritas, obyektivitas, dan kompetensi mempengaruhi perubahan kualitas audit sedangkan sisanya sebesar $24,8 \%$ perubahan kualitas audit dipengaruhi oleh variabel lain yang tidak diteliti dalam penelitian ini.

\section{DAFTAR PUSTAKA}

Ardiani, Nurul, Emrinaldi Nur DP dan Nur Azlina. 2012. Pengaruh Audit Tenure, Disclosure, Ukuran KAP, Debt Default, Opinion Shopping dan Kondisi Keuangan TerhadapPenerimaan Opini 
Pengaruh Pengalaman Kerja, Independensi.... (Veby K. W., Iwan I., Muh. Achsin)

Audit Going ConcernPada Perusahaan RealEstate dan Property di BursaEfek Indonesia. Jurnal Ekonomi. Volume 20. Nomor 4. Desember 2012. Hal 121.

Arens, Alvin A., et al, 2007. Auditing and Assurance Services - An Integrated Approach, Prentice Hall.

Auditor Internal. 2010. Kode Etik Auditor Internal. www.auditorinternal.com. Diakses 25 Agustus 2013.

Bouman, Marinus J, dan Bradley Wray E (1997). Judgement and Decision Making, Part II: Expertise, Consensus and Accuracy, Behaviour Accounting Research: Fondation and Frontiers, American Accounting Association, Pg. 89- 123 .

Carolita, Metha Kartika. 2012. Pengaruh Pengalaman Kerja, Independensi, Objektivitas, Integritas, Kompetensi dan Komitmen Organisasi Terhadap Kualitas Audit. (Studi pada Kantor Akuntan Publik di Semarang). Fakultas Ekonomika dan Bisnis. Universitas Diponegoro. Semarang.

Christiawan. Yulius Jogi. 2002. Kompetensi Dan Independensi Akuntan Publik: RefleksiHasil Penelitian Empiris. Jurnal Akuntansi \& Keuangan Vol. 4, No. 2, Nopember 2002: 79 - 92.

Eisenhardt, K.M. 1989. Agency Theory: An Assessment and review. Academy of management review. Vol 14.

Hanafi, Mamduh. 2008. Manajemen Keuangan. BPFE. Yogyakarta.

Hardiningsih, Pancawati dan Rachamawati Meita Oktaviani. 2013. Pengaruh Due Professional Care, Etika dan Tenur Terhadap Kualitas Audit (Perspektif
Expectation Theory). Diponegoro Journal of Accounting. Hal 1-12.

Hartadi, Bambang. 2009. Pengaruh Fee Audit, Rotasi Kap, Dan Reputasi Auditor Terhadap Kualitas Audit Di BursaEfek Indonesia. Ekuitas: Jurnal Ekonomi dan Keuangan ISSN 1411-0393 Akreditasi No. 110/DIKTI/Kep/2009. Universitas Teknologi Yogyakarta. hal 84-104.

Hartono, Jogiyanto. 2008. Teori Portofolio dan Analisis Investasi. BPFE. Yogyakarta.

Hasibuan, SP,M. 2007. Manajemen Sumber Daya Manusia. Bumi Aksara. Jakarta.

Ikatan Akuntan Indonesia. 2001. Standar Profesional Akuntan Publik. Salemba Empat. Jakarta.

Indah, Siti NurMawar. 2010. Pengaruh Kompetensi Dan Independensi Auditor Terhadap Kualitas Audit (Studi Empiris Pada Auditor Kap Di Semarang). Fakultas Ekonomi Universitas Diponegoro. Semarang.

Infobanknews. 2009. Menkeu Bekukan Izin 8 Akuntan Publik dan Kantor Akuntan Publik. http:// www.infobanknews.com/2009/09/ menkeu-bekukan-izin-8-akuntanpublik-dan-kantor-akuntan-publik/. Diakses tanggal 09 Agustus 2013.

Jansen, M.C., and W.H. Meckling. 1976. Theory of The Firm: Managerial Behaviour Agency Cost and Ownership Structure. Jurnal Of Finance Economic. Vol 3, No. 4: page 305360.

Kusharyanti. 2003. Temuan Penelitian Mengenai Kualitas Audit dan Kemungkinan Topik Penelitian di Masa 
Ekonomika-Bisnis Vol. 5 No.1 Bulan Januari Tahun 2014. Hal 63-74

Datang. Jurnal Akuntansi Manajemen. Edisi Desember 2003. Hal 25-34.

Kusuma, Henda Sandika dan Kawedar, Warsito. 2010. Pengaruh Pelaksanaan Etika Profesi dan Kecerdasan Emosional Terhadap Pengambilan KeputusanBagiAuditor (StudiEmpiris Pada Kantor Akuntan Publik (KAP) dan Badan Pemeriksa Keuangan (BPK) di Semarang. Jurnal akuntansi. Universitas Diponegoro. semarang. Hal 1-29.

Kusuma, Novanda Friska Bayu Aji. 2012. Pengaruh Profesionalisme Auditor, Etika Profesi dan Pengalaman Auditor Terhadap Pertimbangan Tingkat Materialitas. Program Studi Akuntansi Jurusan Pendidikan Akuntansi. Fakultas Ekonomi. Universitas Negeri Yogyakarta.

Kusumasari. 2009. 8 KAP yang dibekukan Pemerintah. Jumat 09 Oktober 2009. erisyakusumasari.blogspot.com/ 2009_10_01_archive.htmlý.

Leonora, Sylvie, Yuliawati Tan dan Aurelia Carina Sutanto. 2012. Analisis Hubungan Masa perikatan Audit dengan kualitas audit. Calyptra: Jurnal Ilmiah Mahasiswa Universitas Surabaya Vol 1 No 1 (2012). Hal 1-20.

Marsellia, Meiden Carmel dan Budi Hermawan. 2013. Pengaruh Kompetensi dan Independensi Terhadap Kualitas Audit DenganEtika Auditor sebagai variabel Moderator (Studi Empiris Pada Auditor Di KAP Big Four Jakarta). Jurnal Akuntansi Institut Bisnis dan Informatika Indonesia (IBII) hal 1-15.
Masrizal. 2010. Pengaruh pengalaman dan pengetahuan audit terhadap pendeteksian temuan kerugian daerah (studi pada auditor inspektorat aceh). Jurnal telaah \& riset akuntansi, Vol. 3. No. 2. Juli 2010 Hal. 173-194

Muid, Dul dan Reza Minanda. 2013. Analisis Pengaruh Profesionalisme, Pengetahuan Mendeteksi Kekeliruan, Pengalaman BekerjaAuditor, danEtika Profesi Terhadap Pertimbangan Tingkat Materialitas Akuntan Public (Studi Empiris PadaAuditor KAPDi Semarang). Diponegoro Journal of Acconting. Volume 1 Nomor 1 Tahun 2013. Hal 1-8. http://ejournals1.undip.ac.id/index.php/accounting.

Mulyadi. 2002. Auditing. Salemba Empat. Jakarta.

Nuratama, I Putu. 2011. Pengaruh Tenur dan Reputasi Kantor Akuntansi Publik Pada Kualitas Audit Dengan Komite Audit Sebagai Variabel Moderasi (Studi Kasus Pada Perusahaan Manufaktur Yang Terdaftar di BEI Tahun 2004-2009). Program Pascasarjana Universitas Udayana Denpansar.

Pratama, Vip dan Tendi Haruman. 2005. Kepuasan Kerja: Konsep, teori, pendekatan dan Skema Pengukurannya. Jurnal Bisnis, Manajemen dan Ekonomi, Volume 6 No.3. Februari 2005. hal 487-502.

Robbins, S.P., T.A. Judge. 2008. Perilaku Organisasi. Salemba Empat. Jakarta.

Sabrina Kdan Indira Januari. 2012. Pengaruh Pengalaman, Keahlian, Situasi Audit, Etika danGender Terhadap Ketepatan Pemberian Opini Auditor Melalui Skeptisisme ProfesionalAuditor (Studi 
Pengaruh Pengalaman Kerja, Independensi.... (Veby K. W., Iwan I., Muh. Achsin)

Kasus Pada KAPBig Four di Jakarta). Diponegoro Journal of Acconting. Sistem Informasi, etika dan Auditing. Hal 1-34.

Salim, Annisa Rahmatika. 2012. Pengaruh Pengalaman Kerja, Independensi, Kompetensi dan Integritas Terhadap Kualitas Audit (Studi Empiris Pada Kantor Akuntan Publik di Kepulauan Riau, Sumatera Barat dan Riau). Jurnal Akuntansi Fakultas Ekonomi Universitas Riau. Hal 1-15.

Samsi, Nur. 2013. Pengaruh Pengalaman Kerja, Independensi dan Kompetensi Terhadap Kualitas Audit: Etika Auditor Sebagai Variabel Pemoderasi. Jurnal Ilmu dan Riset Akuntansi. Volume 1 Nomor 2, Maret 2013. Hal 207-226.

Silaban, Adanan. 2009. Perilaku Disfungsional Auditor Dalam Pelaksanaan Program Audit (Studi Empiris di Kantor Akuntan Public). Disertasi untuk Memperoleh Derajat Doktor Ilmu Ekonomi Konsentrasi Akuntansipada Universitas Diponegor Semarang. Program Doktor Ilmu Ekonomi Universitas Diponegoro.

Silalahi, Gabriel Amin. 2003. Metodologi Penelitian dan Studi Kasus. Cetakan Pertama. CV. Citramedia. Sidoarjo.

Singgih, Elisha Muliani dan Icuk Rangga Bawono. 2010. Pengaruh Independensi, Pengalaman, Due Professional Care Dan Akuntabilitas Terhadap Kualitas Audit (Studi pada Auditor di KAP"Big Four" di Indonesia). Simposium Nasional Akuntansi/ SNA XIII. Universitas Jenderal Soedirman Purwokerto. www.sna13 purwokerto.com. Hal 1-24.
Sugiono. 2008. Metode Penelitian Bisnis (Pendekatan Kuantitatif, Kualitatif dan $R \& D)$. Cetakan Kesebelas. Penerbit Alfabeta. Bandung.

Suhartini dan Romy Gustiansyah. 2004. Analisis Motivasi Kehadiran Mahasiswa fakultas Ekonomi Universitas IslamIndonesia(Pendekatan Teori Pengharapan) Jurnal Siasat Bisnis (JSB) No. 9 Vol. 1 JUNI 2004. Hal 107-122.

Sukriah, Ika, Akram dan Biana Adha Inapty. 2013. Pengaruh Pengalaman Kerja, Independensi, Obyektifitas, Integritas dan Kompetensi Terhadap Kualitas Hasil Pemeriksaan. jurnal aspsia13. Hal 1-10.

Utami, Ratna. Analisis Perbedaan Profesionalisme Auditor Senior dan Auditor Yunior (Studi Terhadap Auditor Yang Bekerja Pada KAP di Kota Malang). Jurnal Humanity. Vol 6 No.2. Maret 2011. Hal 121-126. Versi online:http://ejournal.umm.ac.id/ index.php/humanity/article/view/1395.

Werastuti, Desak Nyoman Sri. 2013. Pengaruh Auditor Client Tenure, Debt Default, Reputasi Auditor, Ukuran Klien Dan Kondisi Keuangan Terhadap Kualitas Audit Melalui Opini Audit Going Concern. VOKASI Jurnal Riset Akuntansi. Vol. 2 No.1, April 2013, ISSN 2337 - 537X. hal 99-116. 
